\title{
PENCIPTAAN PENGETAHUAN TENTANG TANAMAN OBAT HERBAL DAN TANAMAN OBAT KELUARGA
}

\author{
Encang Saepudin ${ }^{1}$, Agus Rusmana ${ }^{2}$, Agung Budiono ${ }^{3}$ \\ ${ }^{1,2,3}$ Program Studi Ilmu Perpustakaan Universitas Padjadjaran \\ 1 encangsaepudin1971@gmail.com, ${ }^{2}$ Agus.rusmana@unpad.ac.id, \\ 3abudfik.108@gmail.com
}

\begin{abstract}
This study aims to determine the process of knowledge creation process which starts from expanding process of knowledge knowledge, sharing, and conceptualization of knowledge about medicinal plants conducted by a team of PKK initiators at Cisondari Village Pasir jambu District of Bandung Regency. By using qualitative methods and case study approaches and techniques of data collection through observation, interviews, and literature study, the research results indicate that the process of creation of knowledge about medicinal plants conducted by the team of PKK initiators at Cisondari Village Pasirjambu District of Bandung Regencyhave been done well. One thing that is still lacking is that knowledge documentation process has not been carried out. Thishas not been done because the oral culture among the people is stronger than the culture of writing, so the innovations that have been created only stored as tacit in the mind of every person. Principally, the main goal of knowledge management is to encourage sustainability of knowledge within an organization or certain social group so that this knowledge can be used to encourage replication in the body of the organization, creates innovation, and gave birth to a new generation .
\end{abstract}

Keyword: Knowledge management, creation of knowledge, sharing of knowledge, tacit, explicit.

ABSTRAK - Penelitian ini bertujuan untuk mengetahui proses penciptaan pengetahuan mulai dari proses memperluas pengetahuan, berbagi pengetahuan, dan konseptualisasi pengetahuan tentang tanaman obat keluarga yang dilakukan oleh tim penggerak PKK Desa Cisondari Kabupaten Bandung. Dengan menggunakan metode kualitatif dan pendekatan studi kasus serta teknik pengumpulan data melalui observasi, wawancara, dan studi pustaka hasil kajian menunjukkan bahwa proses penciptaan pengetahuan tentang tanaman obat keluarga yang dilakukan oleh tim penggerak PKK Desa Cisondari Kabupaten Bandung sudah dilakukan dengan baik. Satu hal yang masih kurang yakni proses pendokumentasian pengetahuan belum dilakukan dengan baik. Proses itu tidak dilakukan karena dikalangan masyarakat budaya lisan lebih kuat bila dibandingkan dengan budaya tulis sehingga beberapa hasil inovasi yang telah tercipta hanya tersipan secara tacit didalam pemikiran setiap orang. Pada prinsipnya, tujuan utama pengelolaan pengetahuan yaitu mendorong keberlanjutan pengetahuan di dalam suatu organisasi atau kelompok sosial tetentu sehingga pengetahuan tersebut dapat digunakan untuk mendorong terjadinya replikasi di dalam tubuh organisasi, menciptakan inovasi, dan melahirkan generasi baru.

Kata Kunci: Manajemen pengetahuan, penciptaan pengetahuan, berbagi pengetahuan, tacit, explicit.

\section{PENDAHULUAN}

Salah satu pengetahuan yang berkembang di pedesaan-khususnya di Masyarakat Desa Cisondari Kecamatan Pasirjambu Kabupaten Bandung, yakni pengetahuan tanaman obat keluarga (Toga). Tumbuh-tumbuhan obat herbal menjadi salah satu unsur penting dalam kehidupan masarakat karena berbagai manfaatnya, baik sebagai sumber makanan maupun untuk medis. Meskipun keampuhan sesungguhnya dari tanaman tersebut belum banyak dibuktikan secara ilmiah, akan tetapi 
sebagai salah satu alternatif penyembuhan penyakit tertentu, tanaman-tanaman tersebut sudah dipergunakan secara turun-temurun melalui studi tentang pengobatan tradisional dan pengetahuan asli penduduk dan memberikan hasil yang diharapkan dalam proses penyembuhan (Balick, A, \& Cox, 1996).

Namun, sejalan dengan perkembangan pengetahuan bidang kedokteran yang melahirkan berbagai jenis obat yang mengandung kimia, kepercayaan masyarakat terhadap kemampuan obat herbal semakin turun. Salah satu faktor yang menyebabkan hilangnya kepercayaan masyarakat terhadap khasiat obatobatan tradisional adalah terputusnya pengetahuan tentang obat-obatan tradisional yang dimiliki oleh nenek moyang bangsa Indonesia. Selain itu, obat modern lebih cepat terasa khasiatnya bila dibandingkan dengan obat-obat herbal. Tanaman-tanaman obat tradisional/herbal, yang sangat kecil efek sampingnya, semakin lama semakin tidak mendapat tempat di masyarakat umum. Mereka lebih percaya terhadap obatobatan modern dengan segala macam efek sampingnya.

Hal inilah yang dikhawatirkan oleh Aliadi, bahwa hilangnya pengetahuan penduduk asli tentang pengelolaan sumber daya alam (baca: tanaman obat) akan menyebabkan hilangnya kearifan tradisional dan juga berarti awal kehancuran dari bangsa. Hilangnya pengetahuan tersebut akan menyebabkan hilangnya acuan dalam pengelolaan sumber daya alam yang khas bersifat etnis (Aliadi, 2002). Dengan demikian, perlu segera dilakukan langkah-langkah konkerit untuk mengelola pengetahuan tersebut, khususnya pengetahuan tentang tanaman obat herbal dan tanaman obat keluarga agar terselamatkan dan menjadi aset sosial budaya bangsa yang membanggakan.

Oleh karena itu, pengetahuan tentang tanaman obat keluarga ini perlu terus dikembangankan sehingga terus terjadi proses pencitaan pengetahuan diantara kelompok masyarakat yang mengembangkannya dalam hal ini yakni tim penggerak PKK desa Cisondari Kabupaten Bandung. Dengan berjalannya proses penciptaan pengetahuan, Inovasi bisa terus terjadi. Seperti kita ketahui bersama bahwa untuk menciptakan pengetahuan baru atau inovasi adalah dengan menggali potensi yang ada dari tiap individu dan memanfaatkan pengetahuan seseorang berdasarkan pengalamannya ataupun keahliannya. Artinya inovasi itu lahirnya dari pengetahuan sumber daya manusia itu sendiri bukan melalui mesin atau asset tangible lainnya. Oleh karena itu, agar dapat terus mengembangkan inovasi yang unik dan kreatif, maka organisasi tidak semata-mata hanya bertumpu pada sumber daya finansial, bangunan, tanah, teknologi, dan asset-asset lain yang bersifat tangible saja. Justru perkembangan saat ini menunjukkan fakta bahwa organisasi apapun seharusnya bertumpu pada aset pengetahuan, baik itu pengetahuan tacit maupun eksplisit (Sangkala, 2013).

Selain itu, Sangkala (2007) mengemukakan bahwa dalam proses penciptaan pengetahuan terdapat berbagai tahapan yakni (1) memperluas pengetahuan dengan mengikuti pelatihan dan 
sebagainya, (2) pembentukan tim untuk menciptakan konsep baru yang kemudian dikristalisasikan, (3) diujicobakan untuk mendapat feedback sampai pada lahirnya suatu produk.

Dalam proses penciptaan pengetahuan perlu dibangun saling percaya baik antarindividu dengan individualnya, maupun antarindividu dengan pimpinan organisasi. Bila rasa saling percaya tidak mampu ditanamkan akan timbul kondisi dimana semakin tinggi kompetensi individu-individu mengakibatkan semakin rendah modal intelektual. Nilai-nilai kebersamaan (share values), yang disusun bersama-sama oleh individu-individunya harus menjadi landasan yang dipercaya untuk meraih cita-citanya. Budaya saling percaya mempercayai yang dilandasi oleh nilai-nilai kebersamaan akan mendorong terciptanya jejaring (network) dan aliansi strategis (strategic alliance) yang sinergistik.

Berdasarkan kepada latar belakang di atas, penelitian ini akan memfokuskan kajian tentang penciptaan pengetahuan tentang tanaman obat keluarga (Toga). Hasil yang ingin dicapai dari penelitian ini ialah:

1. Untuk mengetahui proses perluasan pengetahuan tentang obat herbal dan tanaman obat keluarga oleh tim Penggerak PKK di Desa Cisondari Kecamatan Pasir Jambu Kabupaten Bandung?

2. Untuk mengetahui berbagi pengetahuan tentang obat herbal dan tanaman obat keluarga oleh tim Penggerak PKK di
Desa Cisondari Kecamatan Pasir Jambu Kabupaten Bandung?

3. Untuk mengetahui konseptualisasi pengetahuan tentang obat herbal dan tanaman obat keluarga oleh tim Penggerak PKK di Desa Cisondari Kecamatan Pasir Jambu Kabupaten Bandung?

\section{TINJAUAN PUSTAKA}

Pengetahuan obat herbal dan tanaman obat keluarga masyarakat pedesaan diperoleh secara tacit dan explisit. Sangkala menyatakan bahwa, organisasi apapun seharusnya bertumpu pada aset pengetahuan, baik itu pengetahuan tacit maupun eksplisit (Sangkala, 2013). Masyarakat pedesaan sebagai organisasi kecil dapat mengembangkan pengetahuan yang dimiliki masyarakatnya.

Ini dapat melalui proses penciptaan pengetahuan. Ada 3 (tiga) proses penciptaan pengetahuan yang dapat dikembangkan (1) memperluas pengetahuan dengan mengikuti pelatihan dan sebagainya, (2) pembentukan tim untuk menciptakan konsep baru yang kemudian dikristalisasikan, (3) diujicobakan untuk mendapat feedback sampai pada lahirnya suatu produk (Sangkala, 2013). Di dalam proses penciptaan pengetahuan di Masyarakat Desa Cisondari Kecamatan Pasirjambu Kabupaten Bandung, dianalisis melalui model SECI Nonaka, yang terdiri dari socialization, externalization, combination, internalization (Nonaka, 1998). Akhirnya, ini menghasilkan pengalaman atau pengetahuan baru. Rincian 
lebih mendalam tergambarkan dalam bagan di bawah ini:

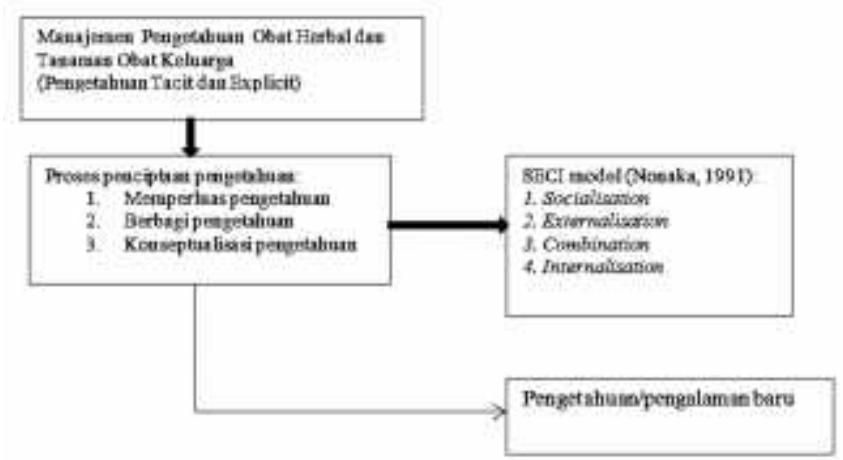

Gambar 1. Proses penciptaan pengetahuan/ pengalaman baru

Sumber: Adaptasi dari berbagai rujukan dan teori

\section{METODE PENELITIAN}

Penelitian ini menggunakan metode kualitatif dengan pendekatan studi kasus (Travers, 2001). Pendekatan studi kasus dipilih dalam penelitian ini karena penelitian ini mengenai kehidupan satu atau beberapa komunitas, organisasi atau perorangan yang dijadikan unit analisis, dengan menggunakan pendekatan kualitatif. Disamping itu, penelitian kualitatif bertujuan untuk mempertahankan bentuk dari perilaku manusia dan mempertahankan kualitas-kualitasnya (Mulyana 2008, 150).

Selain itu, pemilihan studi kasus sebagai pendekatan penelitian karena penelitian ini berangkat dari fenomena kontemporer yang terdapat di lapangan yaitu sudah mulai hilangnya pengetahuan masyarakat tentang obat herbal dan tanaman obat keluarga (TOGA) oleh masyarakat. Selanjutnya penelitian ini dilakukan untuk menjawab pertanyaan penelitian, bagaimana kegiatan manajemen pengetahuan tentang obat herbal dan tanaman obat.

\section{HASIL DAN PEMBAHASAN}

Penelitian mengenai penciptaan pengetahuan tentang tanaman obat herbal dan tanaman obat keluarga ini menitikberatkan pada aspek memperluas pengetahuan, berbagi pengetahuan, dan konseptualisasi pengetahuan. Secara rinci hal tersebut dibahas berikut ini,

\section{Memperluas Pengetahuan}

Tahapan ini mengakumulasi tacit knowledge berdasarkan pengalaman yang dimiliki. Kualitas pengetahuan tacit dipengaruhi oleh 2 faktor, yang pertama adalah keragaman pengalaman individu dan kedua adalah kualitas pengetahuan terhadap pengalaman yang merupakan penjelmaan pengetahuan ke dalam komitmen pribadi yang telah melekat. Proses memperluas pengetahuan para anggota PKK Desa Cisondari Kecamatan Pasirjambu baik anggota PKK tingkat desa maupun anggota PKK tingkat RW dilakukan dengan berbagai cara yakni mengadakan pelatihan baik yang dilakukan oleh PKK tingkat desa secara internal maupun dengan cara mengundang pakar di bidang kesehatan, penyuluhan, dan belajar mandiri. Hal ini sejalan dengan pendapatnya Nonaka dalam Sangkala, bahwa langkah awal dalam proses penciptaan pengetahuan adalah dengan perluasan pengetahuan terlebih dahulu. Pada proses ini ada 
berbagai upaya peningkatan kualitas individu pegawai dengan cara tacit knowledge yang dimiliki individu diarahkan kepada upaya untuk mempengaruhi aspek yang relevan dengan explicit knowledge. Beberapa upaya peningkatan kualitas yang diterjemahkan oleh Nonaka yaitu melalui proses pelatihan dan self learning (Sangkala, 2013).

\section{a. Kegiatan Pelatihan}

Pelatihan atau training sebagai suatu kegiatan yang bermaksud untuk memperbaiki dan mengembangkan sikap, tingkah laku ketrampilan, dan pengetahuan dari karyawannya sesuai dengan keingina perusahaan (Honeycutt, Jakarta). Dengan demikian, pelatihan yang dimaksudkan adalah pelatihan dalam pengertian yang luas, tidak terbatas hanya untuk mengembangkan ketrampilan sematamata. Kegiatan pelatihan ini dimotori oleh pihak Pokja IV yang bergerak dalam bidang pengelolaan Program Kesehatan, Kelestarian Lingkungan Hidup dan Perencanaan Sehat. Menurut ketua pokja empat ada beberapa tujuan dari pelatihan ini yakni meningkatkan pemahaan para anggota PKK dalam bidang kesehatan termasuk pengenalan obat-obat alternatif dan untuk lebih mengenalkan program-program PKK desa kepada para anggota. Kegiatan pelatihan ini selain dilakukan dengan cara mendatangkan para ahli ke desa, kegiatan yang paling sering adalah mengikuti pelatihan ke luar. Dalam hal ini mengikuti pelatihan yang dilaksanakan oleh pihak luar misalnya pelatihan yang diselenggarakan oleh pihan PKK tingkat kecamatan, Kabupaten, dan Dinas Kesehatan

\section{b. Kegiatan Penyuluhan}

Kegiatan penyuluhan merupakan sebuah kegiatan yang dilakukan dengan tujuan untuk merubah perilaku seseorang. Kegiatan penyulluhan yang sering dilakukan oleh pika PKK desa Cisondari terutama oleh pihak pokja empat yakni penyuluhan tentang kesehatan. Penyuluhan kesehatan adalah kegiatan pendidikan yang dilakukan dengan cara menyebarkan pesan, menanamkan keyakinan, sehingga masyarakat tidak saja sadar, tahu, dan mengerti, tetapi juga mau dan bisa melakukan suatu anjuran yang ada hubungannya dengan kesehatan. Kegiatan penyluhan kesehatan dilakukan secara berkala oleh tim penggerak PKK tingkat desa. Kegiatan penyuluhan ini dilaksanakan baik secara formal maupun informal. Secara formal dilakukan dalam bentuk pertemuan rutin bulanan. Kegiatan ini dilakukan secara keliling mulai ditingkat balai desa sampai tingkat RW. Sedangkan penyuluhan secara tidak formal disampaikan secara 
terpadu dalam kegiatan-kegiatan lain seperti kegiatan muludan, safari terawih, dan kegiatankegiatan lain terutama dalam kegiatan keagamaan dan kemasyarakatan. Agar penyuluhan kesehatan di masyarakat dapat mencapai hasil yang diharapkan diperlukan perencanaan yang matang dan terarah sesuai dengan tujuan program penyuluhan kesehatan masyarakat berdasarkan kebutuhan kesehatan masyarakatsetempat. Penyuluhan kesehatan masyarakat di masyarakat biasanya berkaitan dengan pembinaan wilayah binaan Puskesmas atau oleh karena kejadian luar biasa seperti wabah dan lain sebagainya

\section{c. Belajar Mandiri}

Pembelajaran mandiri (self directed learning) dapat diartikan sebagai mata proses, dimana individu mengambil inisiatif dengan atau tanpa bantuan orang lain. Kegiatan yang dilakukan oleh individu tersebut adalah mencakup mendiagnosis kebutuhan belajar, merumuskan tujuan belajar, mengidentifikasi sumber belajar, memilih dan melaksanakan strategi belajar dan menilai hasil belajar. Konsep belajar mandiri pada dasarnya menekankan pada kreatifitas dan inisiatif peserta didik. Akan tetapi pada kondisi tertentu, secara sistematik peserta didik dapat meminta bantuan/bimbingan pada pendidik, disini peran pendidik lebih menekankan sebagai fasilitator. Belajar mandiri sangat penting untuk perkembangan seseorang karena (a) Orang-orang yang mengambil inisiatif dalam belajar lebih banyak dan lebih baik daripada orang yang tergantung pada pendidik, (b) Cara belajar ini sejalan dengan proses alamiah perkembangan jiwa, (c) Munculnya konsep-konsep atau teori-teori baru dalam pendidikan yang menekankan tanggung jawab belajar pada peserta didik

\section{Berbagi Pengetahuan}

Sharing tacit knowledge sebagai salah satu proses utama dalam knowledge management, pada hakekatnya adalah penciptaan kesempatan yang luas untuk belajar (learning) kepada seluruh anggota organisasi sehingga dapat meningkatkan kompetensinya secara mandiri. Namun, perspektif ini tetap bersifat personal kecuali mereka mengartikulasikan dan memperluasnya melalui interaksi sosial, dan salah satu caranya adalah dengan membentuk self-organizing team dimana anggota berkolaborasi untuk menciptakan konsep (Sangkala, 2013). Tahapan transfer pengetahuan juga dapat dikatakan sebagai tahap yang paling sulit dilaksanakan dalam proses knowledge management. Selain itu untuk mentransfer pengetahuan dibutuhkan pengetahuan mengenai komunikasi sehingga 
menyulitkan individu yang sebenarnya mau mentransfer pengetahuan yang dimilikinya namun kurang memahai cara mengkomunikasikan pengetahuan tersebut dengan efektif. Untuk lebih efektifnya proses budaya transfer pengetahuan, maka organisasi setidaktidaknya harus memenuhi berbagai prasyaratan yaitu membangun kepercayaan (trust) dan keterbukaan, serta penggunaan fasilitas berbagi pengetahuan seperti dalam rapat atau briefing, kemudian melalui via internet (chatting atau e-mail). Proses berbagi dapat terbentuk melalui proses sosial pada kultur organisasi yang menghargai aktivitas berbagi pengetahuan. Proses tersebut dapat berlangsung secara tradisional melalui diskusi dan kolokium, maupun melalui medium modern dengan berbasiskan teknologi. Untuk lebih efektifnya proses budaya transfer pengetahuan, sebuah organisasi setidaktidaknya harus memenuhi prasyaratan yakni terbangunnya kepercayaan dan keterbukaan, tersedianya fasilitas, dan adanya kerjasama tim.

\section{a. Membangun Kepercayaan dan}

\section{Keterbukaan}

Untuk membangun kebiasaan untuk saling berbagi pengetahuan, pertama dibutuhkan kepercayaan satu sama lain. Pegawai harus senantiasa saling percaya agar antara mereka dapat dengan leluasa mensharing atau mentransfer pengetahuan dalam dirinya masing-masing.

Membangun kepercayaan juga hal yang tidak mudah, naluri manusia biasanya susah untuk mudah percaya orang lain apalagi untuk mau membagi pengetahuannya kepada orang lain bisa saja berdampak negatif bagi dirinya. Tapi tidak sedikit pula yang mudah atau senang berbagi ilmunya dengan orang lain. Tipe orang seperti ini adalah tipe yang mudah bergaul dan mudah percaya terhadap orang lain yang menurutnya pantas. Di dalam organisasi PKK desa Cisondari sudah terbentuk kepercayaan dan keterbukaan diantara anggota PKK. Mereka sudah merasa satu keluarga dan senantiasa saling membantu dan berbagi

\section{b. Ketersediaan Falitas}

Di desa Cisondari terutama di dalam tim penggerak PKK proses sharing sudah berjalan dengan baik. Hal-hal yang di-share disini umumnya menyangkut tugas pokok dan fungsi tim penggerak PKK yang terbagi atas empat pokja. Untuk lebih berjalannya proses sharing dibentuk suatu fasilitas yang memungkinkan setiap anggota penggerak PKK dapat mengeluarkan ide, pengalaman, atau pengetahuan yang masih tersimpan di dalam diri masing-masing individu (tacit knowledge). Adapun fasilitas berbagi 
pengetahuan di Tim penggerak PKK

Desa Cisondari yakni rapat rutin, surat edaran, papan pengumunan, dan dialog antaranggota

\section{c. Kerjasama Tim}

Kerjasama tim merupakan salah satu unsur fundamental dalam proses sharing pengetahuan. Tim merupakan sekelompok orang yang memiliki visi yang sama dan berasal dari latar belakang yang berbeda pula. Dengan adanya tim, organisasi akan memperoleh penyelesaian masalah dengan cepat dan tepat. Dalam sebuah tim, orang-orang merasa lebih nyaman untuk mengajukan masalah- masalah yang terjadi dan dapat dengan segera memperoleh bantuan dari pekerjapekerja lainnya berupa solusi yang akan digunakan untuk menanggulangi masalah- masalah yang dihadapi. Kerjasama tim juga akan meningkatkan kepercayaan diri, komunikasi dan kemandirian.

Agar manajemen pengetahuan khususnya sharing knowledge dapat berjalan dengan efektif dan efisien, maka dibentuk sebuah tim khusus yang menangani. Tim ini akan memicu proses penciptaan pengetahuan khususnya sharing tacit knowledge agar timbul ide kreatif dan inovatif dalam memenuhi kebutuhan informasi untuk pengembangan organisasi. Kerja sama tim di PKK desa Cisondari tergambar dalam struktur organisasi PKK. Struktur organisasi PKK di Desa Cisondari teah berjalan dengan baik. Di dalam tim pengerak PKK Desa Cisondari terdiri atas ketua tim penggerak PKK tingkat desa yang dibantu oleh empat kelompok kerja sampai pengurus tingka RT. Keempat kelompok kerja ini memiliki tugas dan peran masing-masing.

Barkaitan dengan pengelolaan pengetahuan tentang tanaman obat keluarga yang dilaksanakan di lingkungan tim penggerak PKK desa Cisondari secara khusus menjadi tanggung jawab Pokja empat yakni pokja yang membidangi Program Kesehatan, Kelestarian Lingkungan Hidup dan Perencnaan Sehat. Salah satu proses pengelolaan pengetahuan tanaman obat keluarga yakni berbagi pengetahuan bidang tersebut kepada pokja atau para kader PKK yang lainnya.

Seperti kita ketahui bahwa salah satu fungsi obat herbal dan tanaman obat keluarga adalah sebagai sarana untuk mendekatkan tanaman obat kepada upaya-upaya kesehatan masyarakat yang antara lain meliputi: upaya preventif (pencegahan), upaya promotif (meningkatkan derajat kesehatan) dan upaya kuratif (penyembuhan penyakit). Untuk melestarikan fungsi dari penanaman obat tersebut, perlu 
adanya pemeliharaan pengetahuan, baik dengan cara saling berbagi pengalaman, dialog, mengaplikasikan metode atau mensimulasi produk dari pengetahuan yang didapatkan, serta menjadikan pengetahuan baru untuk setiap penduduk desa menjadi pengalaman pribadi, melalui cara transfer pengetahuan (sharing knowledge). Proses transfer pengetahuan tentang tanaman obat keluarga yakni dengan menggunakan empat model konversi pengetahuan, yakni: sosialisasi, eksternalisasi, kombinasi dan internalisasi:

a. Socialization (Sosialisasi), merupakan proses transfer pengetahuan secara pengetahuan tacit dari seorang individu kepada individu lainnya. Nonaka menjelaskan, "socialization involves the sharing of tacit knowledge between individuals" (Nonaka, 1998). Model sosialisasi merupakan bentuk direct communication. Melalui model sosialisasi, proses konversi pengetahuan tacit baru dapat dilakukan melalui berbagi pengalaman, misalnya dengan bersama-sama tinggal dalam lingkungan yang sama, baik secara formal maupun informal seperti interaksi sosial di luar jam kerja. Pengetahuan tacit bisa juga diperoleh dari pasien maupun pemasok obat herbal dan tanaman obat dengan berinteraksi bersama. Adapun sistem yang diciptakan oleh masyarakat desa Cisondari dalam menciptakan suasana untuk saling berbagi pengetahuan (ide dan pengalaman) adalah sebagai berikut:

- Melalui proses pembelajaran dengan seseorang yang mengerti tentang tanaman obat

- Melalui diskusi informal antar masyarakat

- Serta obrolan santai yang dilakukan masyarakat dengan masyarakat lainnya melalui interaksi untuk membahas secara rileks masalah yang sedang dihadapi.

b. Externalization (Eksternalisasi), adalah proses mengungkapkan pengetahuan tacit menjadi pengetahuan eksplisit. Setelah menjadi eksplisit, pengetahuan mengkristal dan menjadi dasar bagi pengetahuan baru. Contoh proses ini adalah pembuatan/simulasi produk baru, metode maupun konsep yang akan diterapkan. Externalization requires the expression of tacit knowledge and its translation into comprehensible forms that can be 
understood by other. (Nonaka 1998, 43). Proses transformasi pengetahuan obat herbal dan tanaman obat di desa Cisondari secara eksternalisasi tidak terjadi. Hal ini terjadi karena pengetahuan tentang tanaman obat keluarga tidak terdokumentasi secara baik. Masyarakat tidak ada yang mencatat semua manfaat dan kegunaan dari tanaman obat tersebut baik dari hasil diskusi formal maupun dari obrolan santai. Masyarakat Desa Cisondari lebih banyak pengembangan pengetahuan ini melalui komunikasi lisan sehingga tidak terjadi konversi pengetahuan dari tacit ke eksplisit. Apabila terdapat masyarakat yang lupa tentang manfaat dan kegunaan obat tersebut, mereka cenderung mengabaikannya dan tidak berusaha untuk menanyakan kembali

\section{c. Combination}

(Kombinasi), merupakan proses mengubah pengetahuan eksplisit menjadi lebih komplek dan sistematis. Pengetahuan eksplisit dari dalam dan luar organisasi dikumpulkan dan dikombinasikan untuk membentuk pengetahuan baru yang kemudian disebarkan kepada masyarakat. Pada proses kombinasi pun sama dengan proses eksternalisasi, yakni belum dilakukan, walaupun konon katanya penulisan tentang obat herbal dan tanaman obat secara sistematis pernah dicatat dan dibuat dalam bentuk buku. Namun selama melakukan penelitian tidak diperoleh dokumen yang dimaksud

d. Internalization (Internalisasi), merupakan proses memanifestasikan pengetahuan eksplisit menjadi tacit. Melalui internalisasi pengetahuan eskplisit yang terbentuk kemudian disebarkan dan diubah menjadi pengetahuan tacit oleh tiap-tiap individu. Jadi, seluruh pengetahuan baru yang telah diberikan kepada masyarakat kemudian diproses serta disaring oleh masing-masing individu, akan tersimpan dalam memori individu tersebut dalam bentuk tacit pengetahuan yang dilakukan pada masyarakat desa Cisondari yaitu konsep "belajar bersama sambil bekerja". Masyarakat dilibatkan langsung dalam pencarian obat herbal dan tanaman obat. Masyarakat belajar langsung bersama dengan tim penggerak PKK desa. Biasanya mereka biasanya dilibatkan langsung dalam pemeliharaan 
tanaman obat keluarga mulai dari penanaan tanaman di pekarangan masing-masing sampai pada pengujicobaan khasiat tanaman obat tersebut.

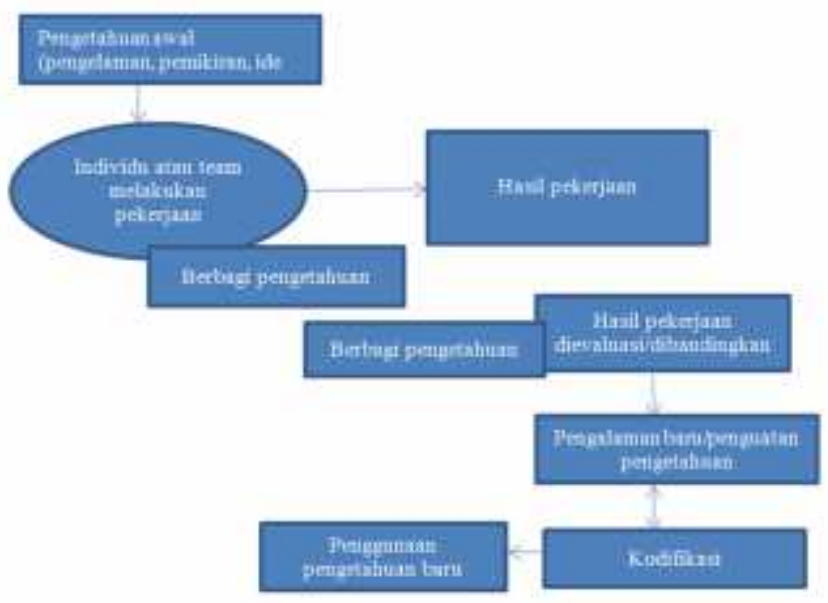

Bagan 1. Model penciptaan pengetahuan di Tim penggerak PKK Desa Cisondari

Sumber: Analisis hasil penelitian

\section{SIMPULAN}

Berdasarkan hasil pembahasan di atas, maka dapat ditarik kesimpulan sebagai berikut:

1. Proses penciptaan pengetahuan tentang tanaman obat keluarga yang dilakukan oleh tim penggerak PKK Desa Cisondari Kabupaten Bandung sudah dilakukan dengan baik. Satu hal yang belum dilakukan adalah pendokumentasian pengetahuan yang telah tercipta

2. Proses itu tidak dilakukan karena dikalangan masyakat budaya lisan lebih kuat bila dibandingkan dengan budaya tulis sehingga beberapa hasil inovasi yang telah tercipta hanya tersipan secara tacit di dalam pemikiran setiap individu.

\section{DAFTAR PUSTAKA}

Aliadi. (2002). Sistem Pengetahuan dan Teknologi Lokal dalam Pembangunan Berkelanjutan di Indonesi.

Balick, J. M., A, P., \& Cox. (1996). Plants, People and Culture. The Science of Ethnobotany.

Honeycutt, J. (Jakarta). Knowledge Management Strategies: Strategi Manajemen Pengetahuan. 2000: Elex Media Komputindo.

Nonaka, I. (1998). "The Concept of "Ba" Building A Foundation For Knowledge Creation.". California Management Review Vol.4 No. 3, 40-54.

Sangkala. (2013). Knowledge Management. Jakarta: Grafindo Persada.

Travers, M. (2001). Qualitative Research Through Case Studies. Sage Publications, Sage Publications. 
